\title{
ANALISIS PENGARUH PROMOSI JABATAN DAN DISIPLIN \\ KERJA PADA PRODUKTIVITAS KERJA KARYAWAN \\ PADA PT. POS INDONESIA (PERSERO) \\ DI KABUPATEN SITUBONDO
}

\section{ANALYSIS OF EFFECT OF PROMOTION POSITION AND WORK DISCIPLINE ON EMPLOYEE PRODUCTIVITY IN PT. POS \\ INDONESIA (PERSERO) \\ IN DISTRICT SITUBONDO}

\author{
Triska Dewi Pramitasari \\ Program Studi Manajemen, Fakultas Ekonomi, \\ Universitas Abdurachman Saleh Situbondo \\ triskadewi ps@yahoo.com
}

\begin{abstract}
Abstrak
Tujuan penelitian ini adalah untuk mengetahui apakah promosi jabatan dan disiplin kerja berpengaruh nyata secara simultan maupun secara parsial terhadap produktivitas kerja karyawan. Teknik pengambilan sampel dalam penelitian ini dilakukan dengan metode sensus, dimana sampel yang digunakan sama dengan jumlah populasinya yaitu seluruh karyawan tetap PT. Pos Indonesia (Persero) di Kabupaten Situbondo yang berjumlah 24 orang. Sedangkan teknik analisis data yang dipergunakan adalah Analisa Regresi Berganda, uji $t$, uji $F$, dan uji Dominan (Nilai Koefisien Standardized Beta) (dengan menggunakan program SPSS 16.0 for Windows dengan tingkat signifikan 0,05). Hasil penelitian ini menyimpulkan bahwa variabel promosi jabatan dan disiplin kerja berpengaruh nyata secara simultan terhadap produktivitas kerja karyawan. Variabel promosi jabatan tidak berpengaruh nyata secara parsial terhadap produktivitas kerja karyawan sedangkan untuk variabel disiplin kerja berpengaruh nyata secara parsial terhadap produktivitas kerja karyawan. Dan disiplin kerja berpengaruh dominan terhadap produktivitas kerja karyawan.
\end{abstract}

Kata kunci: Promosi Jabatan, Disiplin Kerja, Produktivitas Kerja Karyawan

\section{Abstract}

The purpose of this study is to determine whether position promotion and job discipline significantly affect simultaneously or partially on employee productivity. The sampling technique in this research is done by census method, where the sample is used equal to the number of population that is all the permanent employees of PT. Pos Indonesia (Persero) in Situbondo regency which amounted to 24 people. Data analysis techniques used are Multiple Regression Analysis, $t$ test, $F$ test, and Dominant test (Standardized Beta Coefficient Value) (using SPSS 16.0 for Windows program with significant level 0,05). The results of this study conclude that the variables of position promotion and job discipline have a significant effect simultaneously on employee 
productivity. Position promotion variable has no real partial effect on employee productivity while for job discipline variable significantly partially effect on employees productivity. And job discipline has a dominant effect on employee productivity.

Keywords: Position Promotion, Job Discipline, Employee Productivity.

\section{PENDAHULUAN}

Kebutuhan hidup yang tak kalah penting di era globalisasi ini adalah kebutuhan akan jasa pengiriman barang. Banyaknya penduduk yang saling mengirim barang dari tempat yang jauh membuat jasa ini menjadi sangat penting. Berdasarkan kenyataan tersebut banyak bermunculan jasa pengiriman barang swasta, sedangkan jasa pengiriman pemerintah dari dahulu sampai sekarang hanya satu, yaitu PT Pos Indonesia (Persero).

PT. Pos Indonesia (Persero) di Kabupaten Situbondo yang terletak di Jalan Ahmad Yani No. 131 ini adalah suatu perusahaan yang bersifat jasa dimana tujuan dari perusahaan itu sendiri adalah berorientasi kepada kepuasan pelanggan. Perusahaan senantiasa berupaya untuk meningkatkan mutu layanan yang berorientasi kepada kepuasan pelanggan dengan memperhatikan efisiensi, efektivitas dan produktivitas sumber daya manusia (karyawan) serta kemampuan usaha melalui pemanfaatan ilmu pengetahuan dan teknologi.

Upaya perusahaan dalam menghadapi arus globalisasi seperti saat ini sumber daya manusia (SDM) memegang peranan yang sangat dominan dalam aktivitas atau kegiatan perusahaan. Dalam usaha pencapaian tujuan perusahaan, maka perlu adanya peningkatan produktivitas kerja karyawan. Produktivitas kerja pada hakekatnya meliputi sikap yang senantiasa mempunyai pandangan bahwa metode kerja hari ini harus lebih baik dari pada metode kerja hari kemarin, dan hasil yang dapat diraih esok hari harus lebih banyak atau lebih bermutu daripada hasil yang diraih hari ini. Untuk mencapai produktivitas kerja karyawan yang tinggi bukan hal yang mudah untuk dilaksanakan. Beberapa faktor yang sangat penting untuk mencapai produktivitas kerja karyawan adalah pelaksanaan promosi jabatan dan disiplin kerja pada para karyawan, karena hal tersebut merupakan salah satu faktor penentu bagi keberhasilan dan kemajuan dalam mencapai tujuan perusahaan.

Promosi jabatan merupakan salah satu bagian dari program penempatan yang dilaksanakan oleh perusahaan. Penempatan karyawan dilakukan dengan membuat penyesuaian terhadap kebutuhan perusahaan yang berhubungan dengan perencanaan untuk memperoleh orang yang tepat pada posisi yang tepat (right man on the right place). Promosi jabatan dilakukan olah perusahaan untuk mengisi kekosongan formasi, ini disebabkan oleh beragam hal mulai dari pensiun hari tua hingga pengunduran diri karyawan. Untuk itu perusahaan mencari karyawan yang telah ada yang dinilai memiliki kualifikasi sesuai dengan jabatan baru yang dibutuhkan dari yang dibutuhkan untuk dapat dipromosikan.

Disiplin kerja merupakan salah satu faktor yang terpenting dalam meningkatkan produktivitas kerja karyawan, karena dengan adanya disiplin kerja, karyawan akan mampu mencapai produktivitas kerja yang maksimal. Tingkat disiplin dapat diukur melalui ketaatan pada peraturan yang telah ditentukan oleh perusahaan dan dari kesadaran pribadi. Karyawan akan mematuhi atau mengerjakan semua tugasnya dengan baik dan bukan mematuhi tugasnya itu dengan paksaan. Karyawan harus memiliki prinsip dan memaksimalkan potensi kerja, agar karyawan lain mengikutinya sehingga dapat menanamkan jiwa disiplin dalam bekerja.

Melihat besarnya peranan pelaksanaan promosi jabatan dan disiplin kerja bagi kehidupan sekaligus kelansungan karier karyawan di perusahaan, maka para karyawan berlomba-lomba 
untuk dapat bersaing dalam mengisi jabatan yang akan dipromosikan serta akan selalu mematuhi segala peraturan yang berlaku di perusahaan. Selain itu perusahaan pun turut melihat manfaat lain yaitu dengan meningkatnya produktivitas kerja karyawan maka akan memberikan keuntungan yang optimal bagi perusahaan.

Adapun perumusan masalah pada penelitian ini adalah :

1. Apakah terdapat pengaruh nyata secara simultan atau serentak antara komponen variabel dari promosi jabatan dan disiplin kerja terhadap produktivitas kerja karyawan?

2. Apakah terdapat pengaruh nyata secara parsial antara komponen variabel dari promosi jabatan dan disiplin kerja terhadap produktivitas kerja karyawan?

3. Komponen variabel manakah yang paling dominan berpengaruh nyata diantara promosi jabatan dan disiplin kerja terhadap produktivitas kerja karyawan?

Berdasarkan pokok permasalahan maka tujuan dari penelitian ini adalah :

1. Untuk mengetahui pengaruh nyata secara simultan komponen variabel dari promosi jabatan dan disiplin kerja terhadap produktivitas kerja karyawan.

2. Untuk mengetahui pengaruh nyata secara parsial komponen variabel dari promosi jabatan dan disiplin kerja terhadap produktivitas kerja karyawan.

3. Untuk mengetahui komponen variabel paling dominan yang berpengaruh nyata diantara promosi jabatan dan disiplin kerja terhadap produktivitas kerja karyawan.

\section{Produktivitas Kerja}

Setiap perusahaan atau organisasi dalam usaha pencapai tujuannya dipengaruhi dan ditentukan oleh produktivitas tenaga kerjanya. Dengan demikian adanya produktivitas tenaga kerja yang tinggi maka akan meningkatkan produktivitas perusahaan. Pada dasarnya pengertian produktivitas mencakup sikap mental yang berpandangan bahwa kehidupan hari ini harus lebih baik dari hari kemarin dan yang dicapai besok harus lebih baik dari hari ini. Orang yang memiliki sikap demikian akan selalu terdorong untuk menjadi dinamis, kreatif, inovatif, serta terbuka ide-ide baru dalam perubahan-perubahan. Produktivitas adalah perbandinag antara output (hasil) dengan input (masukan). (Drs. H. Malayu S.P. Hasibuan, 2003:126). Sedangkan menurut Drs. Muchdarsyah Sinungan (2003:12), produktivitas merupakan perbandingan antara keluaran dan masukan serta mengutarakan cara pemanfaatan baik terhadap sumber-sumber dalam memproduksi suatu barang atau jasa. Melihat pendapat-pendapat diatas maka bisa disimpulkan bahwa produktivitas kerja karyawan merupakan hasil yang dicapai persatuan waktu tertentu secara efisien dari keseluruhan sumber daya yang digunakan dengan adanya peran serta tenaga kerja atau karyawan.

\section{Promosi Jabatan}

Promosi Jabatan mempunyai arti penting bagi para karyawan secara keseluruhan, dengan adanya pemberian kesempatan promosi jabatan, karyawan akan termotivasi untuk bekerja sama dan berprestasi maka akhirnya tugas-tugas yang diberikan oleh perusahaan akan dilaksanakan dengan sebaik-baiknya.

Marihot Tua Efendi Hariandja (2002:157) berpendapat bahwa : "Promosi Jabatan adalah menaikkan jabatan seseorang ke jabatan lain yang memiliki tanggung jawab yang lebih besar, gaji yang lebih besar, dan pada level organisasi yang lebih besar ". Selanjutnya menurut Drs. Malayu S.P. Hasibuan (2001:175) : "Promosi adalah peningkatan status (jabatan) seorang 
karyawan, seperti karyawan percobaan / calon pegawai (capeg) menjadi karyawan tetap atau karyawan operasional diangkat menjadi karyawan manajerial".

Berdasarkan pendapat-pendapat para ahli diatas, maka dapat ditarik kesimpulan bahwa promosi jabatan adalah perpindahan posisi / jabatan atau pekerjaaan/penugasan kembali seseorang karyawan dari tingkat yang lebih rendah ke tingkat yang lebih tinggi. Adanya peningkatan jabatan, maka tugas, tanggung jawab, serta wewenang akan meningkat pula. Pada umumnya promosi jabatan juga diikuti oleh peningkatan gaji atau dan fasilitas-fasilitas lainnya. Hasil dari promosi yang dilakukan dapat membentuk perilaku karyawan terhadap pekerjaan yang bisa meningkatkan semangat kerja karyawan dengan baik.

\section{Disiplin Kerja}

Disiplin kerja adalah sikap mental yang tercermin dalam perbuatan atau tingkah laku perorangan, kelompok atau masyarakat berupa kepatuhan atau ketaatan terhadap peraturan dan ketentuan yang ditetapkan baik oleh pemerintah atau etik, norma dan kaidah yang berlaku dalam masyarakat untuk tujuan tertentu (Drs. Muchdarsyah Sinungan, 2003:146).

Pendapat lain merumuskan bahwa disiplin kerja adalah kesadaran dan kesediaan seseorang menaati semua peraturan dan norma-norma sosialmyang berlaku. Kesadaran adalah sikap seseorang yang secara sukarela menaati semua peraturan dan sadar akan tugas dan tanggung jawabnya, kesediaan adalah suatu sikap, tingkah laku, dan peraturan perusahaan, baik yang tertulis maupun tidak. (Drs. Malayu S.P. Hasibuan, 2001:113).

Berdasarkan dua pendapat diatas maka dapat disimpulkan bahwa disiplin kerja adalah sikap pada pegawai untuk berperilaku sesuai dengan peraturan yang telah ditetapkan dimana dia bekerja.

\section{HIPOTESIS}

Hipotesis yang diajukan dalam penulisan ini adalah:

1. Diduga terdapat pengaruh nyata secara simultan atau serentak diantara promosi jabatan dan disiplin kerja terhadap produktivitas kerja karyawan.

2. Diduga terdapat pengaruh nyata secara parsial diantara promosi jabatan dan disiplin kerja terhadap produktivitas kerja karyawan.

3. Diduga faktor yang paling dominan pengaruhnya adalah disiplin kerja di dalam meningkatkan produktivitas kerja karyawan.

\section{METODE PENELITIAN}

\section{Rancangan Penelitian}

Penelitian yang dilakukan merupakan penelitian eksplanatori (explanatory Research) yaitu penelitian yang bertujuan untuk menganalisis hubungan-hubungan antara satu variabel dengan variabel lainnya atau bagaimana suatu variabel mempengaruhi variabel lainnya.

\section{Populasi dan Sampel}

Populasi dalam penelitian ini adalah seluruh karyawan tetap PT. Pos Indonesia (Persero) di Kabupaten Situbondo. Teknik pengambilan sampel dalam penelitian ini dilakukan dengan metode sensus, sehingga diperoleh jumlah sampel yang sama dengan jumlah populasinya yaitu seluruh karyawan tetap PT. Pos Indonesia (Persero) di Kabupaten Situbondo yang berjumlah 24 orang dengan rincian sebagai berikut : 
Tabel 1. Sampel Penelitian

\begin{tabular}{clc}
\hline No. & \multicolumn{1}{c}{ Unit } & Jumlah Karyawan Tetap \\
\hline 1 & Bagian Pelayanan & 5 \\
2 & Bagian Pengolahan Pos & 4 \\
3 & Bagian SDM / Pemasaran & 2 \\
4 & Bagian Akuntansi & 1 \\
5 & Bagian Keuangan & 2 \\
6 & Bagian Kantor Cabang & 10 \\
\hline & TOTAL & 24 \\
\hline
\end{tabular}

Sumber : PT. Pos Indonesia (Persero) di Kabupaten Situbondo

\section{Definisi Operasional variabel}

1. Promosi Jabatan (X1) adalah menaikkan jabatan seseorang ke jabatan lain yang memiliki tanggung jawab yang lebih besar, gaji yang lebih besar, dan pada level organisasi yang lebih besar. (Marihot Tua Efendi Hariandja, 2002:157). Adapun indikatornya terdiri dari : Kejujuran, Loyalitas, Tingkat Pendidikan, Pengalaman Kerja, Inisiatif,

2. Disiplin Kerja (X2) adalah sikap mental yang tercermin dalam perbuatan atau tingkah seseorang berupa kepatuhan atau ketaatan terhadap peraturan dan ketentuan yang ditetapkan (Drs. Muchdarsyah Sinungan, 2003:146). Adapun indikatornya terdiri dari : Disiplin waktu, Disiplin peraturan, Disiplin tanggung jawab.

3. Produktivitas Kerja ( $\mathrm{Y}$ ) adalah perbandingan antara keluaran dan masukan serta mengutarakan cara pemanfaatan baik terhadap sumber-sumber dalam memproduksi suatu barang atau jasa (Drs. Muchdarsyah Sinungan, 2003:12). Adapun indikatornya terdiri dari: Kemampuan, Motivasi, Insentif (Perangsang), hubungan antara tenaga kerja dan pimpinan organisasi, Disiplin kerja.

\section{Metode Pengujian Instrumen}

Penelitian tentang pengaruh promosi jabatan dan disiplin kerja terhadap produktivitas kerja karyawan ini menggunakan kuesioner sebagai instrumen pengumpul data. Data dikumpulkan melalui kuisioner kemudian dilakukan skala pengukuran dengan menggunakan Skala Likert dimana kriteria penilaian digolongkan dalam 5 tingkatan dengan penilaian Skor 5 untuk jawaban SS (sangat setuju) hingga Skor 1 untuk jawaban STS (sangat tidak setuju) (Sugiono, 2010:86).

Data dalam penelitian mempunyai kedudukan yang sangat penting karena data berfungsi sebagai alat pembuktian hipotesis. Valid atau tidaknya data sangat menentukan bermutu atau tidaknya data tersebut. Hal ini tergantung instrumen yang digunakan, yakni memenuhi asas validitas dan reliabilitas.

\section{Uji Validitas}

Analisis ini ditujukan sejauh mana ketepatan dan kecermatan suatu alat ukur dalam melakukan fungsi ukurannya. Sebuah instrumen dikatakan valid apabila mampu mengukur apa yang diinginkan. Uji validitas dapat diketahui dengan membandingkan antara $r$ hitung dari hasil olahan komputer dengan $r$ tabel dari tabel $r$ product moment. Syarat minimum untuk dianggap memenuhi syarat adalah nilai rhitung $>$ rtabel $(0,413)$ jika nilai rhitung $<0,413$ maka dinyatakan tidak valid. Uji validitas dilakukan dengan cara menghitung korelasi antara masing - masing pernyataan skor butir $(X)$ dengan skor total $(Y$ ) menggunakan rumus "Koefisien Korelasi Pearson" (Product Moment Coefisien or Corelation) (Bambang Tri Cahyono, 1996:279) dengan rumus sebagai berikut: 


$$
\mathbf{r}_{\mathbf{x y}}=\frac{N\left(\sum x y\right)-\left(\sum x\right)\left(\sum y\right)}{\sqrt{\left[N \sum x^{2}-\left(\sum x\right)^{2}\left[N \sum y^{2}-\left(\sum y\right)^{2}\right]\right.}}
$$

dimana $\quad r_{x y}=$ Koefisien korelasi Product Moment

$\mathrm{N} \quad=$ Jumlah sampel

$\mathrm{X} \quad=$ Skor butir

$\mathrm{Y} \quad=$ Skor total

\section{Uji Reliabilitas}

Pengujian reliabilitas dalam penelitian ini menggunakan metode Alpha Croanbach's dengan formula sebagai berikut:

$$
\alpha=\left[\frac{k}{k-1}\right]\left[1 \frac{\sum s_{j}^{2}}{s_{x}{ }^{2}}\right]
$$

Dimana:

$\mathrm{a}=$ Koefisien Alpha Croanbach

$\mathrm{k}=$ Banyaknya belahan tes

$\mathrm{Sj} 2=$ Varians belahan $=1,2,3, \ldots \ldots . \mathrm{k}$

Sx2 $=$ Varians skors tes

Nilai Alpha minimum 0,6 untuk syarat diterimanya reliabilitas, sedangkan jika kurang dari 0,6 reliabilitasnya dikategorikan kurang baik (Sugiyono, 2002:221). Sedangkan untuk memenuhi kriteria sebagai instrumen penelitian ini diuji validitas dan reliabilitasnya dengan menggunakan komputer program SPSS 16.0 for windows dengan tingkat signifikan 0,05.

\section{TEKNIK ANALISA DATA}

\section{Analisis Regresi Berganda}

Analisis ini digunakan untuk mengetahui pengaruh nyata variabel independent (promosi jabatan dan disiplin kerja) terhadap variabel dependent (produktivitas kerja karyawan), dimana rumus yang digunakan dalam penelitian ini adalah sebagai berikut (Bambang Tri Cahyono, 1996:219) (menggunakan program SPSS 16.0 for Windows dengan tingkat signifikan 0,05) :

$\mathrm{Y}=\mathrm{a}+\mathrm{b} 1 \mathrm{X} 1+\mathrm{b} 2 \mathrm{X} 2+\mathrm{e}$

Dimana :

$\mathrm{Y}$ = produktivitas kerja karyawan pada PT. Pos Indonesia (Persero) di Kabupaten Situbondo.

$\mathrm{a}=$ konstanta

bx $=$ koefisisen regresi yang menunjukan angka peningkatan atau penurunan variabel dependent yang didasarkan pada variabel independent.

$\mathrm{X} 1$ = promosi jabatan

$\mathrm{X} 2$ = disiplin kerja

$\mathrm{e} \quad=$ error term (residual) 


\section{Pengujian Hipotesis Dengan Uji Secara Serentak Atau Uji F}

Pengujian yang dilakukan menggunakan uji distribusi $\mathrm{F}$ memiliki langkah - langkah sebagai berikut :

1. Membuat formulasi hipotesis

Ho $: b 1=b 2=0$

Artinya tidak ad $\neg$ a pengaruh yang signifikan dari variabel independen $(X)$ secara bersamasama terhadap variabel dependen $(\mathrm{Y})$.

$\mathrm{Ha}: \mathrm{b} 1 \neq \mathrm{b} 2 \neq 0$

Artinya ad $\neg$ a pengaruh yang signifikan dari variabel independen $(X)$ secara bersama sama terhadap variabel dependen $(Y)$.

2. Menentukan level signifikasi dengan tabel F-tabel

3. Menentukan grafik distribusi uji $F$

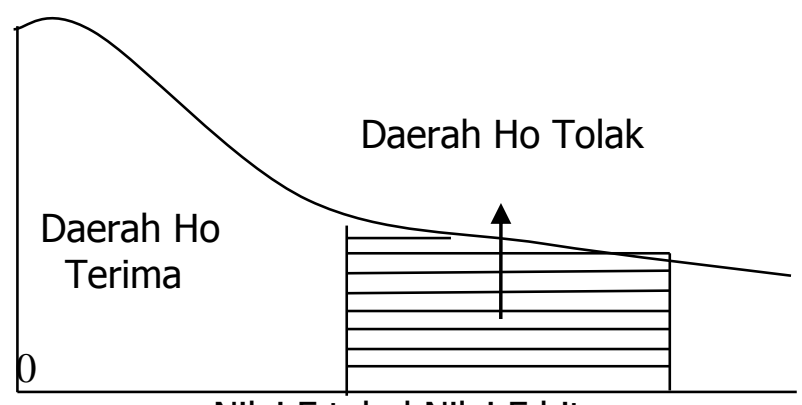

Nilai $F$ tabel Nilai $F$ hitung

Gambar 1. Grafik Distribusi Uji F

Mencari $\mathrm{F}$ - hitung dengan rumus :

$$
\text { F-hitung }=\frac{R^{2} /(k-1)}{\left(1-R^{2}\right) /(n-k)}
$$

Mengambil keputusan

Jika F - hitung < F - tabel, maka Ho diterima

Jika $\mathrm{F}-$ hitung $=\mathrm{F}-$ tabel, maka Ho diterima

Jika F - hitung > F - tabel, maka Ho ditolak

\section{Pengujian Hipotesis Dengan Uji Parsial Atau Uji t}

Adapun langkah - langkah pengujian adalah sebagai berikut (Bambang Tri Cahyono, 1996:230) :

1. Membuat formulasi hipotesis

Ho : b1 = 0 (hipotesis nihil)

Artinya tidak ada pengaruh yang signifikan dari variabel independen $(X)$ terhadap variabel dependen $(Y)$.

Ha : $b 1 \neq 0$ (hipotesis alternatif)

Artinya ada pengaruh yang signifikan dari varibel independen $(X)$ terhadap variabel dependen (Y).

2. Menentukan level signifikasi dengan menggunakan t-tabel.

3. Menentukan grafik distribusi uji $t$

4. Menghitung nilai t-statistik dengan rumus : 


\section{Mengambil keputusan}

Jika $\mathrm{t}$ - hitung $<\mathrm{t}-$ tabel, maka Ho diterima

Jika $\mathrm{t}-$ hitung $=\mathrm{t}-$ tabel, maka Ho diterima

Jika $\mathrm{t}$ - hitung $>\mathrm{t}$ - tabel, maka Ho ditolak

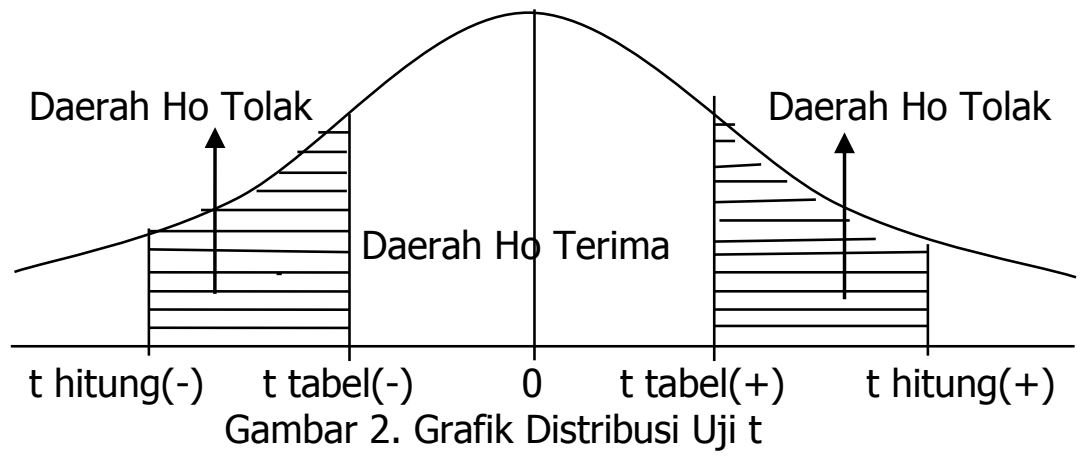

\section{Uji Dominan (Nilai Koefisien Standardized Beta)}

Koefisien Standardized Beta digunakan untuk mengetahui variabel manakah yang paling dominan diantara kedua variabel (X1, X2). Variabel bebas manakah yang memiliki nilai koefisien standardized beta terbesar merupakan variabel dominan dan berpengaruh terhadap variabel terikat $(\mathrm{Y})$ dalam model regresi.

Tabel 2. Rangkuman Hasil Uji Validitas Kuesioner

\begin{tabular}{cccc}
\hline Item & r hitung & r tabel & G. Status \\
\hline & & & \\
Promosi Jabatan & & & \\
Item 1 & 0,797 & 0,413 & Valid \\
Item 2 & 0,647 & 0,413 & Valid \\
Item 3 & 0,741 & 0,413 & Valid \\
Item 4 & 0,823 & 0,413 & Valid \\
Item 5 & 0,671 & 0,413 & Valid \\
Disiplin Kerja & & & \\
Item 1 & 0,767 & 0,413 & Valid \\
Item 2 & 0,720 & 0,413 & Valid \\
Item 3 & 0,607 & 0,413 & Valid \\
Item 4 & 0,833 & 0,413 & Valid \\
Item 5 & 0,673 & 0,413 & Valid \\
Produktivitas Kerja & & & \\
Item 1 & 0,711 & 0,413 & Valid \\
Item 2 & 0,650 & 0,413 & Valid \\
Item 3 & 0,653 & 0,413 & Valid \\
Item 4 & 0,846 & 0,413 & Valid \\
Item 5 & 0,646 & 0,413 & Valid \\
& & & \\
\hline
\end{tabular}

Sumber:Data SPSS

\section{Uji Reliabilitas}

Dari hasil pengolahan dengan program SPSS 16.0 for windows dengan tingkat signifikan 0,05, diperoleh hasil yang terlihat di tabel 2. Dari tabel 2 terlihat bahwa nilai Cronbach's Alpha untuk seluruh variabel $>0,6$ dan probabilitas sig $F<0,05$, ini mengindikasikan bahwa seluruh variabel dinyatakan reliabel. 
Tabel 3. Rangkuman Hasil Uji Reliabilitas Kuesioner

\begin{tabular}{clcccc}
\hline No & \multicolumn{1}{c}{ Variabel } & $\begin{array}{c}\text { Nilai } \\
\text { Alpha }\end{array}$ & Kriteria & Sig & Status \\
\hline 1. & Promosi Jabatan & 0,877 & 0,6 & 0,00 & Reliabel \\
2. & Disiplin Kerja & 0,865 & 0,6 & 0,00 & Reliabel \\
3. & Produktivitas Kerja & 0,852 & 0,6 & 0,00 & Reliabel \\
\hline
\end{tabular}

Sumber : Data SPSS

Tabel 4. Rangkuman Hasil Analisa Faktor

\begin{tabular}{cccc}
\hline Item & $\begin{array}{c}\text { KMO and } \\
\text { Bartlett's Test }\end{array}$ & Kriteria & Sig \\
\hline $\begin{array}{c}\text { Promosi Jabatan } \\
\left(\mathrm{X}_{1}-\mathrm{X}_{15}\right)\end{array}$ & 0,672 & 0,5 & 0,001 \\
\hline $\begin{array}{c}\text { Disiplin Kerja }\left(\mathrm{X}_{2} 1^{-}\right. \\
\left.\mathrm{X}_{25}\right)\end{array}$ & 0,794 & 0,5 & 0,004 \\
\hline $\begin{array}{c}\text { Produktivitas Kerja } \\
\left(\mathrm{Y}_{1}-\mathrm{Y}_{5}\right)\end{array}$ & 0,788 & 0,5 & 0,003 \\
\hline Sumber:Data SPSS & & &
\end{tabular}

\section{Analisis Faktor}

Dari hasil pengolahan dengan program SPSS 16.0 for windows, diperoleh hasil yang terlihat pada tabel 4. Dari hasil analisis kelayakan faktor di atas, didapatkan nilai KMO MSA (KaiserMeyer-Olkin measure of sampling adequacy) untuk seluruh variabel $>0,5$ dan probabilitas sig $<0,05$ (Ghazali,2005), ini berarti bahwa semua sub-variabel pengukuran atau dimensi yang menentukan keberhasilan produktivitas kerja karyawan syah untuk difaktorkan.

\section{Analisis Regresi Linier Berganda}

Berdasarkan hasil analisis data dengan menggunakan program komputer, hasil output dapat diringkas seperti tampak pada tabel berikut :

Tabel 5. Hasil Regresi Linier Berganda

\begin{tabular}{|c|c|c|c|c|c|c|}
\hline \multirow{2}{*}{\multicolumn{2}{|c|}{ Model }} & \multicolumn{2}{|c|}{$\begin{array}{l}\text { Unstandardized } \\
\text { Coefficients }\end{array}$} & \multirow{2}{*}{$\begin{array}{c}\begin{array}{c}\text { Standardized } \\
\text { Coefficients }\end{array} \\
\text { Beta } \\
\end{array}$} & \multirow[b]{2}{*}{$\mathrm{t}$} & \multirow[b]{2}{*}{ Sig. } \\
\hline & & B & $\begin{array}{l}\text { Std. } \\
\text { Error }\end{array}$ & & & \\
\hline \multirow[t]{3}{*}{1} & (Constant) & $\begin{array}{r}-5.676 \mathrm{E}- \\
17\end{array}$ & .123 & & .000 & 1.000 \\
\hline & $\begin{array}{l}\text { PromosiJabata } \\
\mathrm{n}\end{array}$ & .288 & .175 & .288 & 1.641 & .116 \\
\hline & DisiplinKerja & .591 & .175 & .591 & 3.369 & .003 \\
\hline
\end{tabular}

Berdasarkan hasil perhitungan dengan menggunakan program statistik komputer SPSS 16.0 for windows dengan tingkat signifikan 0,05 diperoleh hasil persamaan regresi linier berganda sebagai berikut :

$Y=-5,676+0,288 X 1+0,591 X 2$ 
Interpretasi dari persamaan tersebut adalah sebagai berikut:

1. $a=-5,676$ menunjukkan bahwa apabila tidak ada variabel promosi jabatan dan disiplin kerja $(X 1$, dan X2 =0), maka produktivitas kerja karyawan sebesar $-5,676$. Dalam arti kata produktivitas kerja karyawan akan menurun sebesar $-5,676$ sebelum atau tanpa adanya variabel promosi jabatan dan disiplin kerja $(X 1$, dan $\mathrm{X} 2=0)$.

2. $\mathrm{b} 1=0,288$, yang berarti bahwa promosi jabatan $(X 1)$ mempunyai pengaruh positif terhadap produktivitas kerja karyawan $(\mathrm{Y})$ sebesar 0,288 dan menganggap variabel disiplin kerja (X2) tetap (konstan). Dengan kata lain dapat disebutkan bahwa setiap peningkatan promosi jabatan sebesar satu satuan atau $1 \%$ maka produktivitas kerja karyawan akan mengalami peningkatan sebesar 0,288 satuan atau $28,8 \%$.

3. $b 2=0,591$ yang berarti bahwa disiplin kerja (X2) mempunyai pengaruh positif terhadap produktivitas kerja karyawan sebesar 0,591 dan menganggap promosi jabatan (X1) tetap (konstan). Dengan kata lain dapat disebutkan bahwa setiap peningkatan disiplin kerja sebesar satu satuan atau $1 \%$ maka produktivitas kerja karyawan akan mengalami peningkatan sebesar 0,591 satuan atau 59,1\%.

Dari hasil analisis regresi linier berganda di atas disimpulkan bahwa kedua variabel bebas yaitu promosi jabatan dan disiplin kerja memiliki pengaruh yang positif terhadap variabel terikat yaitu produktivitas kerja karyawan. Dengan kata lain dapat dijelaskan bahwa apabila promosi jabatan dan disiplin kerja mengalami peningkatan maka produktivitas kerja karyawan juga akan mengalami peningkatan.

\section{Pengujian Hipotesis Dengan Uji Secara Serentak Atau Uji F}

Uji $\mathrm{F}$ ini digunakan untuk mengetahui secara bersama-sama pengaruh variabel-variabel independen atau variabel bebas (promosi jabatan dan disiplin kerja) terhadap variabel dependen atau variabel terikat (produktivitas kerja karyawan). Adapun langkah-langkah pengujian sebagai berikut:

1. Menentukan hipotesa

$\mathrm{H} 0: \mathrm{b} 1=\mathrm{b} 2=0$

Artinya tidak ad $\neg$ a pengaruh yang signifikan dari variabel independen $(X)$ secara bersamasama terhadap variabel dependen $(Y)$.

$\mathrm{Ha}: \mathrm{b} 1 \neq \mathrm{b} 2 \neq 0$

Artinya ad $\neg$ a pengaruh yang signifikan dari variabel independen $(X)$ secara bersama sama terhadap variabel dependen $(Y)$.

2. Level of significant $(a)=0,05$

$$
\begin{aligned}
\text { Nilai F tabel } & =a(k-1 ; n-k) \\
& =0,05(3-1 ; 24-3) \\
& =0,05 ; 2 ; 21 \\
& =3,47
\end{aligned}
$$




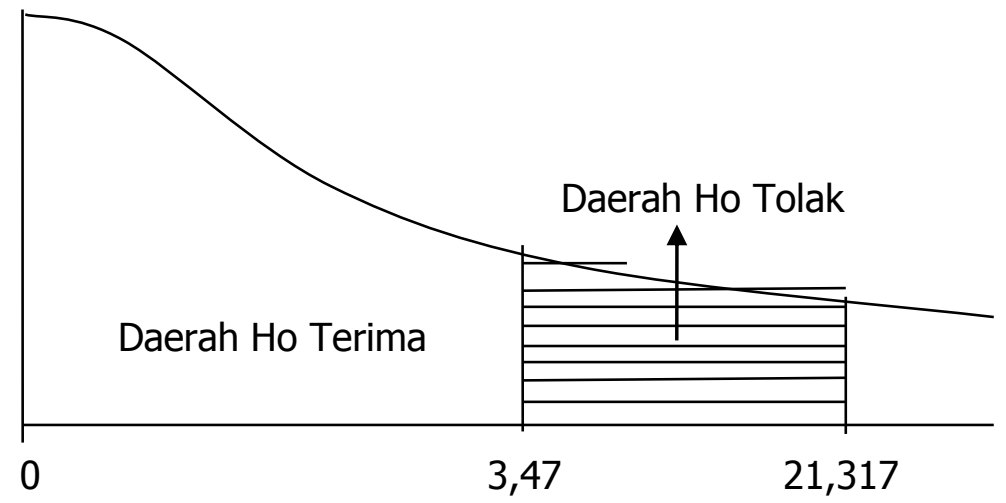

3. Kriteria pengujian

Gambar 3. Grafik Distribusi Uji F

HO diterima apabila Fhitung $\leq$ Ftabel $(3,47)$

HO ditolak apabila Fhitung $>$ Ftabel $(3,47)$

4. Nilai Fhitung sebesar 21,317.

5. Kesimpulan

Nilai Fhitung $(21,317)>$ Ftabel $(3,47)$, maka Ho ditolak berarti menerima Ha yaitu ada pengaruh yang signifikan dari variabel $X$ (promosi jabatan dan disiplin kerja) secara bersamasama terhadap variabel $Y$ (produktivitas kerja karyawan).

\section{Pengujian Hipotesis Dengan Uji Parsial Atau Uji t}

Uji t pada dasarnya menunjukkan seberapa jauh pengaruh satu variabel penjelas secara individual dalam menerangkan variasi variabel terikat. Adapun langkah-langkah pengujian sebagai berikut:

Variabel promosi jabatan (X1) terhadap produktivitas kerja karyawan (Y), Langkah-langkah pengujian:

1. Menentukan hipotesa

$\mathrm{H} 0$ : $\mathrm{b} 1=0$ (tidak ada pengaruh antara promosi jabatan terhadap produktivitas kerja karyawan)

$\mathrm{Ha}: \mathrm{b} 1 \neq 0$ (terdapat pengaruh antara promosi jabatan terhadap produktivitas kerja karyawan)

2. Level of significant (a) $=0,05$ dengan derajat kebebasan ( $d f)=n-k=21$

Nilai ttabel $=a(n-k)$

$$
\begin{aligned}
& =0,05(24-3) \\
& =0,05 ; 21 \\
& =2,08
\end{aligned}
$$

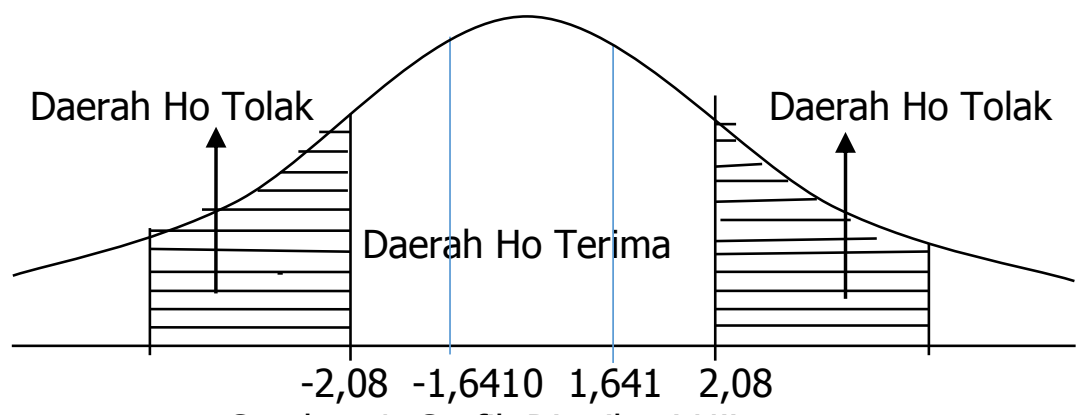

Gambar 4. Grafik Distribusi Uji t

3. Kriteria pengujian

HO diterima apabila $-2,08 \leq$ thitung $\leq 2,08$ 
H0 ditolak apabila thitung $>2,08$ atau thitung $<-2,08$

4. Nilai thitung sebesar 1,641 .

5. Kesimpulan

Nilai thitung $(1,641)<$ ttabel $(2,08)$ dengan nilai signifikansi 0,05 , maka Ho diterima berarti menolak Ha yaitu tidak ada pengaruh yang signifikan antara promosi jabatan (X1) terhadap produktivitas kerja karyawan (Y).

Variabel disiplin kerja (X2) terhadap produktivitas kerja karyawan (Y), Langkah-langkah pengujian:

1. Menentukan hipotesa

H0 : b2 = 0 (tidak ada pengaruh antara disiplin kerja terhadap produktivitas kerja karyawan)

$\mathrm{Ha}:$ b2 $\neq 0$ (terdapat pengaruh antara disiplin kerja terhadap produktivitas kerja karyawan)

2. Level of significant (a) $=0,05$ dengan derajat kebebasan (df) $=n-k=21$

Nilai ttabel $=a(n-k)$

$$
\begin{aligned}
& =0,05(24-3) \\
& =0,05 ; 21 \\
& =2,08
\end{aligned}
$$

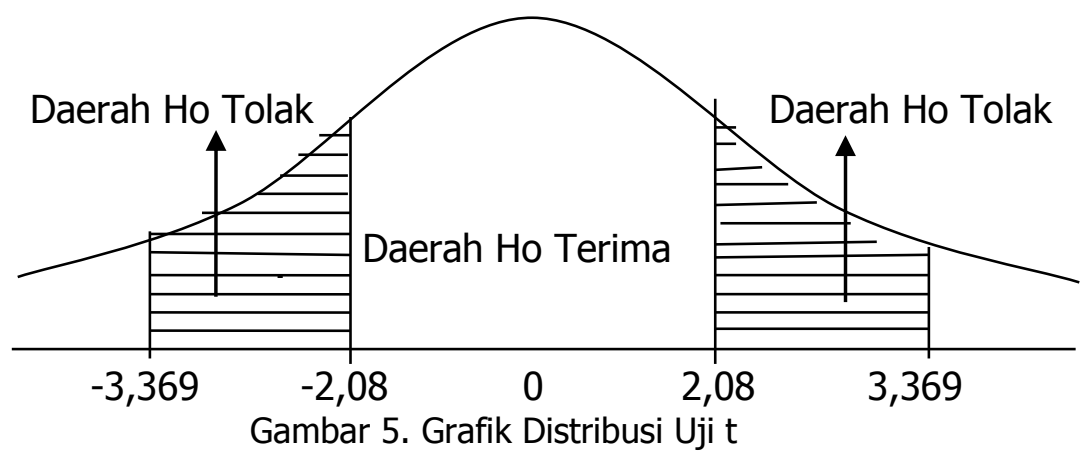

3. Kriteria pengujian

HO diterima apabila $-2,08 \leq$ thitung $\leq 2,08$

$\mathrm{HO}$ ditolak apabila thitung $>2,08$ atau thitung $<-2,08$

4. Nilai thitung sebesar 3,369.

5. Kesimpulan

Nilai thitung $(3,369)>$ ttabel $(2,08)$ dengan nilai signifikasi 0,05 , maka Ho ditolak berarti menerima $\mathrm{Ha}$ yaitu ada pengaruh yang signifikan antara disiplin kerja (X2) terhadap produktivitas kerja karyawan (Y).

\section{Uji Dominan (Nilai Koefisien Standardized Beta)}

Koefisien Standardized Beta digunakan untuk mengetahui variabel manakah yang paling dominan diantara kedua variabel (X1 dan X2). Variabel bebas manakah yang memiliki nilai koefisien standardized beta terbesar merupakan variabel dominan dan berpengaruh terhadap variabel terikat $(Y)$ dalam model regresi.

Berdasarkan hasil olah data nilai koefisien beta variabel promosi jabatan (X1) dan disiplin kerja (X2) adalah sebagai berikut: 
Tabel 6. Hasil Pengujian Pengaruh Dominan

\begin{tabular}{cccc}
\hline \multicolumn{2}{c}{ Produktivitas Kerja } & Koef. Regresi & $t_{\text {hitung }}$ \\
\hline Promosi Jabatan & $\left(\mathrm{X}_{1}\right)$ & 0,288 & 1,641 \\
Disiplin Kerja & $\left(\mathrm{X}_{2}\right)$ & 0,591 & 3,369 \\
\hline
\end{tabular}

Sumber: Lampiran 8

Dari tabel diatas diperoleh hasil bahwa variabel yang berpengaruh dominan terhadap produktivitas kerja karyawan adalah variabel disiplin kerja ( X2 ), hal ini ditunjukkan dengan nilai koefisien standardized beta variabel disiplin kerja lebih besar dibanding promosi jabatan.

\section{PEMBAHASAN}

Proses pencapaian tujuan organisasi atau perusahaan, karyawan atau tenaga kerja mempunyai peran yang penting sebagai pelaksana kegiatan operasional. Untuk itu perusahaan harus memperhatikan kebutuhan hidup karyawan tersebut. Pelaksanaan promosi jabatan dan disiplin kerja merupakan sarana agar karyawan dapat memunuhi kebutuhan hidupnya, karena dengan adanya hal tersebut maka prestasi kerja akan meningkat sehingga produktivitas kerja karyawanpun juga akan meningkat.

Berdasarkan kuesioner yang disebar kepada karyawan PT. Pos Indonesia (Persero) Di Kabupaten Situbondo diketahui bahwa untuk variabel promosi jabatan (X1) dengan indikator kejujuran, loyalitas, tingkat pendidikan, pengalaman kerja, dan inisiatif diperoleh jawaban dengan rata-rata skor 3,71. Hal ini berarti skor berada pada derajat asumsi penelitian yang baik. Dengan demikian perusahaan telah menerapkan program pelaksanaan promosi jabatan dengan sangat baik, sehingga akan berdampak secara positif terhadap produktivitas kerja karyawan.

Berdasarkan kuesioner yang disebar kepada karyawan PT. Pos Indonesia (Persero) Di Kabupaten Situbondo diketahui untuk variabel disiplin kerja (X2) dengan indikator disiplin waktu (kehadiran dan kepatuhan pegawai pada jam kerja, pegawai melaksanakan tugas dengan tepat waktu dan benar), disiplin peraturan dan disiplin tanggung jawab diperoleh jawaban dengan skor 3,74. Hal ini berarti skor berada pada derajat asumsi penilaian baik. Dengan demikian perusahaan telah menerapkan pelaksanaan disiplin kerja dengan sangat baik, sehingga akan berdampak positif terhadap produktivitas kerja karyawan.

Berdasarkan kuesioner yang disebar kepada karyawan PT. Pos Indonesia (Persero) Di Kabupaten Situbondo diketahui untuk variabel produktivitas kerja (Y) dengan indikator kemampuan, motivasi, insentif (perangsang), hubungan antara tenaga kerja dan pimpinan organisasi, dan disiplin kerja diperoleh jawaban dengan rata-rata skor 3,73. Hal ini berarti skor berada pada derajat asumsi penilaian baik.

Uraian di atas dapat diketahui bahwa selama ini pihak PT. Pos Indonesia (Persero) Di Kabupaten Situbondo telah melaksanakan pelaksanaan program promosi jabatan dan disiplin kerja dengan sangat baik. Sehingga dengan adanya hal tersebut memberikan dampak yang positif terhadap produktivitas kerja karyawan.

Hal ini juga telah dibuktikan melalui analisis statistik yaitu diperoleh hasil Uji $F$ yang menyatakan bahwa variabel promosi jabatan (X1) dan disiplin kerja (X2) berpengaruh nyata secara bersama-sama terhadap produktivitas kerja karyawan ( $Y$ ), hal ini ditunjukkan dengan nilai Fhitung $(21,317)>$ Ftabel $(3,47)$. Sedangkan untuk uji t diperoleh hasil yang berbeda dimana nilai thitung untuk variabel X1 lebih kecil dari $t$ tabel $(1,641<2,08)$ sedangkan untuk variabel X2 nilai dari thitung lebih besar dari t tabel $(3,369>2,08)$. Hasil uji t untuk variabel $\mathrm{X} 1$ dinyatakan tidak signifikan karena sampel yang digunakan dalam penelitian ini seluruhnya adalah karyawan tetap, dimana mereka telah memiliki status sebagai karyawan tetap dengan posisi jabatan dan penghasilan yang sudah sesuai dengan keinginan mereka, jadi dalam hal ini tujuan mereka bekerja tidak lagi untuk memperoleh promosi jabatan sehingga pada saat 
diberikan koesioner yang berisi pernyataan-pernyataan tentang promosi jabatan, hasil yang diperoleh tidak memuaskan. Untuk Uji Dominan diperoleh hasil bahwa disiplin kerja mempunyai pengaruh dominan terhadap produktivitas kerja karyawan. Hal ini ditunjukkan dengan nilai koefisien standardized beta terbesar dalam model regresi linier berganda yaitu sebesar 0,591, dimana dapat diartikan walaupun pelaksanaan promosi jabatan baik, akan tetapi disiplin kerja lah yang sangat berperan dalam terhadap produktivitas kerja karyawan.

\section{KESIMPULAN}

Berdasarkan hasil analisis data yang diperoleh, maka dapat diambil beberapa kesimpulan sebagai berikut:

1. Variabel promosi jabatan (X1) dan disiplin kerja (X2) berpengaruh nyata secara simultan atau bersama-sama terhadap produktivitas kerja karyawan $(Y)$ sebesar 63,9 \% . Hal ini ditunjukkan dengan nilai Fhitung $(21,317)>$ Ftabel $(3,47)$ dengan tingkat signifikan $(0,000)$ $<0,05$ dan dari hasil Adjusted $\mathrm{R}$ square sebesar 0,639 atau 63,9\%, berarti jika variabel promosi jabatan (X1) dan disiplin kerja (X2) mengalami peningkatan secara bersama-sama, maka produktivitas kerja karyawan $(Y)$ akan mengalami peningkatan pula dan sebaliknya.

2. Variabel promosi jabatan (X1) tidak berpengaruh nyata secara parsial terhadap produktivitas kerja karyawan $(Y)$, hal ini ditunjukkan dengan nilai thitung lebih kecil dari $t$ tabel $(1,641<2,08)$ berarti jika variabel promosi jabatan (X1) mengalami peningkatan secara parsial, maka tidak akan mempengaruhi produktivitas kerja karyawan ( $\mathrm{Y}$, sedangkan untuk variabel disiplin kerja (X2) berpengaruh nyata secara parsial terhadap produktivitas kerja karyawan $(\mathrm{Y})$, hal ini ditunjukkan dengan nilai thitung lebih besar dari $\mathrm{t}$ tabel $(3,369>2,08)$, berarti jika variabel promosi jabatan $(X 1)$ dan disiplin kerja (X2) mengalami peningkatan secara parsial, maka produktivitas kerja karyawan (Y) akan mengalami peningkatan pula dan sebaliknya.

3. Disiplin kerja berpengaruh dominan terhadap produktivitas kerja karyawan. Hal ini ditunjukkan dengan nilai koefisien standardized beta terbesar dalam model regresi linier berganda yaitu sebesar 0,591, dimana dapat diartikan walaupun pelaksanaan promosi jabatan baik, akan tetapi disiplin kerja yang sangat berperan dalam terhadap produktivitas kerja karyawan.

4. Rata-rata skor yang diberikan responden pada butir - butir pernyataan tentang variabel promosi jabatan $(3,71)$, disiplin kerja $(3,74)$ dan produktivitas kerja karyawan $(3,73)$ nilainya diatas skor 3,41, ini berarti indikator promosi jabatan, disiplin kerja dan produktivitas kerja yang diterapkan di PT. Pos Indonesia ( Persero ) di Kabupaten Situbondo sudah baik/skornya tinggi. 


\section{SARAN}

1. Bagi Perusahaan

a. Untuk meningkatkan produktivitas kerja karyawan yang lebih tinggi, hendaknya perusahaan meningkatkan kedisiplinan kerja karyawan seperti menekan tingkat absensi di dalam memberikan ijin hari libur kepada karyawan dan memberikan uang bonus terhadap karyawan yang mempunyai kedisiplinan yang tinggi.

b. Perusahaan juga hendaknya memberikan perhatian kepada karyawan yang mempunyai kecakapan kerja yang baik dan mempunyai masa kerja yang cukup untuk dipromosikan jabatannya yang lebih tinggi, agar karyawan termotivasi di dalam meningkatkan produktivitas kerjanya.

2. Bagi Peneliti Mendatang

Penelitian yang akan datang sebaiknya mengembangkan penelitian ini dengan menambah variabel lain karena dari hasil uji koefisien determinasi diperoleh nilai R2 sebesar $=0,670$ yang menunjukkan bahwa variabel promosi jabatan dan disiplin kerja berpengaruh terhadap produktivitas kerja karyawan sebesar $67 \%$, sedangkan 33\% sisanya dipengaruhi oleh variabel lain yang tidak diteliti, misalnya motivasi kerja, gaya kepemimpinan, kompensasi dan lain-lain.

\section{DAFTAR PUSTAKA}

Arikunto, S., 2002. Prosedur Penelitian. Edisi Revisi V. Rineka Cipta : Jakarta.

Cahyono, Bambang Tri. 1996. Metode Riset Bisnis. Badan Penerbit IPWI : Jakarta.

Effendi H, Marihot Tua. 2002. Manajemen Sumber Daya Manusia. PT. Gramedia Widiasarana Indonesia: Jakarta.

Ghazali, Imam. 2005. Aplikasi Analisis Multivariate dengan Program SPSS. Diponegoro : Semarang.

Guntur, Ietje S. 1996. Jaminan Sosial Tenaga Kerja. Jakarta : Airlangga.

Hasibuan P, S Malayu. 2001. Manajemen. PT. Bumi Aksara: Jakarta.

Hasibuan P, S Malayu. 2003. Organisasi dan Motivasi. PT. Bumi Aksara: Jakarta.

Hasibuan P, S Malayu. 2006. Manajemen Sumber Daya Manusia. Jakarta : PT Bumi Aksara.

Heidjrahman Ranupandojo, Suad Husnan. 1990. Manajemen Personalia. BPFE: Yogyakarta.

Nasir, M. 1998. Metode Penelitian. Ghalia Indonesia. Jakarta.

Purnomo, Agung S. 2006. Pengaruh Promosi Jabatan dan Disiplin Kerja Terhadap Kinerja Karyawan pada Swalayan Mitra di Kartasura. Tidak Diterbitkan. Skripsi. Surakarta : Universitas Muhammadiyah Surakarta.

Restiani, Hersi. 2005. Studi Pelaksanaan Disiplin Kerja Pegawai di PT Pos Indonesia (Persero) Kantor Pos II Semarang. Tidak Diterbitkan. Skripsi. Semarang : Universitas Negeri Semarang.

Simamora, Henry. 2004. Manajemen Sumber Daya Manusia. Yogyakarta : STIE YKPN. 
Sinungan, Muchdarsyah. 2003. Produktivitas. PT. Bumi Aksara: Jakarta.

Sugiyono, 2002. Metode Penelitian Bisnis. CV Alfabeta. Bandung. 2010. Metode Penelitian Pendidikan. Alfa Beta : Bandung.

Sutinah, Suyanto Bagong. 2007. Metode Penelitian Sosial. Kencana : Jakarta.

Widarjono, Agus. 2010. Analisis Statistika Multivariat Terapan. UPP STIM YKPN : Yogyakarta 